\title{
Evangelos Moutsopoulos, 1930-2021
}

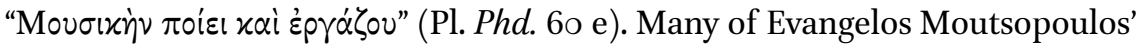
students and kin will remember him repeating — with a pale smile and radiant eyes_-Plato's words, in which he found not only an exhortation to philosophy and hard work, but also the very aim of human life.

On the morning of June 7, 2021, Evangelos Moutsopoulos passed away at the age of 91. Professor Moutsopoulos was born in Athens in 1930. His childhood and early teenage years were marked by the Second World War and the tragic loss of his father. He studied Classics at the University of Athens and Philosophy in Paris. He received his Doctorate in Philosophy (under the supervision of P.-M. Schuhl) from the University of Paris-Sorbonne in 1958. Following a professorship at the University of Aix-en-Provence (1958), he was appointed professor at the Aristotle University of Thessaloniki and, subsequently, at the University of Athens, where he was elected Rector in 1977. In 1984, Evangelos Moutsopoulos was elected full member of the Academy of Athens. He was a visiting professor and a doctor honoris causa of numerous universities as well as a member of many research institutions, academies, and philosophical societies worldwide. He is survived by his beloved wife, Michele, and his nephew, the Greek-French scenographer Yannis Kokkos.

Evangelos Moutsopoulos' interests spanned the History of Philosophy (Ancient, Medieval, and Modern, from the Presocratics to Phenomenology through Byzantine philosophy) and Systematic Philosophy, including the philosophy of art as well as the Philosophy of time and, more especially, the investigation of the notion of "critical time" (kairos). A prolific author of some sixty books, four hundred journal articles, and more than a hundred book reviews, he published mainly in French, Greek, and English but also in Italian and Spanish. He was the editor of Philosophia, the yearbook of the Academy of Athens' Research Center for the Study of Greek Philosophy; he founded and long edited the international philosophical journal Diotima as well as the Corpus Philosophorum Graecorum Recentiorum (CPGR), a series devoted to the publication of the works of Greek philosophers from the 14th century onwards.

One of Professor Moutsopoulos' main research interests lay in Plato and the Platonic tradition. His contributions to the field include: La musique dans l' œuvre de Platon, Paris, P.U.F., (1959) 1989 (Italian ed.: 2002; Greek ed.: 2010); Le problème de l'imaginaire chez Plotin, 4th ed., Paris, Vrin, 200o; Les structures 
de l'imaginaire dans la philosophie de Proclus, Paris, Les Belles Lettres, 1985; Structure, présence et fonctions du kairos chez Proclus, Athens, Acad. of Athens, 2003; La philosophie de la musique dans le système de Proclus, Athens, Acad. of Athens, 2004.

Faitful to Plato's definition of philosophy as "the greatest kind of music" (Phd.61 a), Evangelos Moutsopoulos posited a close link between philosophy and music. Having studied Classical and Byzantine music and Musicology in Athens and Paris (under J. Berghmans and J. Chailley), he developped a strong interest in the philosophy of music (from Aeschylus to Brahms) grounded in his own activity as a composer. His compositions include CEuvres pour piano, vols. 1 and 2, while his Lieder (Digital Press Hellas, Lyra CD o181/95) are inspired by a selection of European (mainly Greek) poetry, including his own verse. His artistic talent also found expression in drawing and landscape painting. In all these activities, he saw different manifestations of beauty, the notion of which he endeavoured to pinpoint in his philosophical work.

A Renaissance Homo Universalis, Evangelos Moutsopoulos was also a man of his time and a man of contradictions brought into harmony. His philosophical nature and unfulfilled vocation to priesthood from a very young age were combined with the temperament and vitality of an enthusiastic and passionate man, who was, however, able to achieve moderation and practice phronesis, living according to his philosophy. We shall not neglect to "pay a cock to Asclepius" (Phd. 118 a).

\section{Irini-Fotini Viltanioti}

University of Crete, Rethymnon, Crete, Greece

viltanioti@uoc.gr 